the positron provided the final proof of the validity of Dirac's theory of the electron, for this theory requires the existence of just such a particle.

Dr. Anderson has also contributed greatly to the study of cosmic radiation itself, particularly by his work on the energy spectrum of the rays and of their energy loss in passing through matter. In connexion with the latter, he has recently shown that electrons with energies at least up to $3 \times 10^{8}$ electron volts do suffer the large radiation energy losses which are predicted by theory. During the last year, Dr. Anderson took his apparatus to the top of Pike's Peak at an altitude of 4,300 metres, and there obtained a large number of cosmic ray photographs by the counter-controlled method. Among these are some of the finest shower photographs yet taken. It is interesting to note that Dr. Anderson's communication to Science, announcing the apparent existence of a positive electron, was only the fourth paper published by him. Dr. Anderson, who is only thirty-one years of age, must certainly be the youngest experimenter in recent decades to make a discovery of such first-class importance; and now he is also to be congratulated on being surely one of the youngest experimental physicists to receive a Nobel prize.

\section{Edward Meyrick, F.R.S.}

Mr. Foward MeYrick will reach the age of eighty-two years on November 24, and his many friends and correspondents all over the world will join with NATURE in good wishes and congratulations on his effective life's work. In 1927, when awarded the Captain Scott Memorial Medal by the South African Biological Society, for his study of South African Microlepidoptera, the president justly remarked that "Mr. Meyrick's is an example of what can be done by a single individual, unsupported, with no financial backing, but devoted to a task that fills his life". Meyrick is a Wiltshireman, still residing at Thornhanger, Marlborough. He was a boy at Marlborough College from 1868 until 1873, and a classical scholar of Trinity College, Cambridge. From 1877 until 1886 he was a schoolmaster at Sydney, Australia, and at Christchurch in New Zealand. He returned to Marlborough College as an assistant master in 1887 and continued there until his retirement in 1914. During the last fifteen years of that period, he was president of the Marlborough College Natural History Society, which has been an inspiration to so many young naturalists, many of them now men of distinction. Marlborough is indeed one of the most fortunate of schools, situated in the beautiful valley of the Kennet between Savernake Forest and the wide and open chalk downs of Wiltshire, with its varied fauna and flora. The country-side is famous for dykes, barrows and hill-forts, and the county contains Stonehenge, Avebury, Old Sarum and Silbury; while the British 'mount' of Marlborough stands within the historic grounds of the College, once a British fort, once a castle, once a mansion, once the "Castle Inn" with its memories of Pitt, now a school, and always famous.
The duties of an assistant master at a public school are so arduous and exacting that it is rather rare for a schoolmaster to achieve the distinction of becoming a fellow of the Royal Society. Meyrick was elected in 1904, largely for his work on Australian Lepidoptera. About nine years later he published his "Handbook of British Lepidoptera" (Macmillan), and in 1927 "A Revised Handbook of British Lepidoptera" (Watkins and Doncaster). In these books Meyrick broke away from the older classification based on fugitive characteristics such as wing patterns and colours, and he depended largely, but not entirely, on the more permanent forms of the veins or neurations of the wings. He was familiar with the MicroIepidoptera of South Africa, Australia and New Zealand, for he was a great traveller, and a student of the moths and butterflies of the whole world. His study of the insects of Australia and New Zealand caused him to reject the Wegener hypothesis that those regions, once united, had drifted a thousand miles apart. Meyrick had a large viewpoint as a naturalist, and the following have been termed, by Comstock, Meyrick's Laws, though perhaps laws is not quite the right word: "No new organ can be produced except as a modification of some previously existing structure." "A lost organ cannot be regained." "A rudimentary organ is rarely re-developed." Most of Meyrick's work will be permanent; other work has come and more will originate from the many pupils to whom he has handed on the lamp of wisdom and the torch of enthusiasm.

\section{Dr. F. Simon}

Dr. F. Simon, who has been appointed to succeed Prof. A. C. G. Egerton as reader in thermodynamics at Oxford (see p. 895), took his degree in Berlin in 1921. He was Privatdozent and extraordinary professor of physics there until 1931. From 1931 until 1933 he was director of the physical-chemical institute of the University of Breslau. He was in California for six months in 1932 as a visiting professor. During the last three years he has been working in the Clarendon Laboratory at Oxford on low temperature research, particularly on the production of very low temperatures by the magnetic cooling method, and on the properties of matter in the neighbourhood of the absolute zero.

\section{J. L. Macadam (1756-1836)}

THE centenary of the death of John Loudon Macadam, which occurs on November 26 (see p. 869), is a reminder of the debt we owe to that group of men who at a critical time in our industrial history were instrumental in making vast improvements in our means of transport. As one of this group, Macadam has a place beside Brindley, the Duke of Bridgewater, Telford, Rennie, Metcalf, Smeaton and others. Macadam was born in Ayr on September 23, 1756. $\mathrm{He}$ lost his father in 1770 and as a boy of fourteen years of age was sent to an uncle in New York. Thirteen years later he returned home comparatively well off, and settled down to the life of a country gentleman in his native country. It was as such 